\title{
Interfaith Marriage And Its Legal Consequences For Children Born According To Islamic Law
}

\author{
Indira Hastuti $^{1^{*}}$, Edy Sanjaya ${ }^{2}$, Budi Prasetyo ${ }^{3}$ \\ ${ }^{1,2,3}$ Faculty of Law, University of 17 August 1945 Semarang, Indonesia \\ * Corresponding author: \\ Email: indirawisnu906@gmail
}

\begin{abstract}
.
Interfaith marriages, which are widely practiced in society, will, in the long term, have a social and psychological impact on children born to these couples. In contrast, in terms of legal aspects, they certainly have legal consequences for children born to couples of different religions. The purpose of this study was to determine the legal implications of interfaith marriages for children born according to Islamic law. Methods This study uses a normative juridical method by reviewing various literature relevant to the studied theme. Data was collected through a literature study to find secondary legal materials pertinent to the prescriptive descriptive approach. The study results indicate that the legal consequences of interfaith marriages are invalid marriages, and children born are not permitted according to Islamic law. According to Islamic law, Interfaith marriages have legal implications for children who are born; namely, children are considered as children born out of wedlock. Children born out of wedlock only have a kinship relationship with their mother and their mother's family.
\end{abstract}

Keywords: Children, interfaith marriage, children, Islamic law, legal consequences

\section{INTRODUCTION}

According to the Indonesian language, marriage comes from the root word marry, which means according to the language dictionary to form a family with the opposite sex; have sex or have sex. Marriage is also called "marriage", comes from the word marriage which according to the language means to collect, include each other, and is used to mean intercourse (wathi). The word marriage itself is often used for the meaning of intercourse (coitus), also for the meaning of the marriage contract [1].

The meaning of marriage is a contract or bond, because in a marriage process there is ijab (a statement of submission from the woman) and kabul (a statement of acceptance from the man). Marriage can also be interpreted as having intercourse [2].

According to Islamic law, especially those regulated in Fiqh, the meaning of marriage or marriage contract is:[3] tien which justifies association and limits rights and obligations as well as mutual assistance between a man and a woman who are not mahrom between the two of them.

Marriage in a normative sense can be seen in the provisions of Article 1 of Law Number 1 of 1974 concerning Marriage which states; Marriage is an inner and outer bond between a man and a woman as husband and wife with the aim of forming a happy and eternal family or household based on the One Godhead. 
The above definition emphasizes that marriage is an inner and outer bond between a man and a woman as husband and wife. This implies that marriage is not possible between a man and a man, or a woman and a woman. Marriage is also impossible between many men and many women. According to Hilman Hadikusumo, of course, it may also not be a marriage if the inner and outer bond is not happy, or the marriage is not eternal and is not based on the One Godhead [4]. According to the provisions of Article 2 of the Compilation of Islamic Law (KHI) Book I on Marriage Law, it is stated that marriage according to Islamic law is marriage, which is a very strong contract or miltsaaqon gholiidhan to obey Allah's commands and carry it out is worship [5]. Marriage is one of study object from marriage law. Marriage law is sub ordinance of family law that focus about interactives between member of family. Interactive between member of family consist of law interactive between husband and wife, law interactive between parents and children, lawa interactive between family with society or government. Scope of family law rul of law about marriage, divorce, property right of marriage couple, childcare, child guardian, child obedience for parents, intervention of governments against law interactive between children with parents, as well as implementation of interactive of parents and child into adoption.

The legal marriage to be association of man and woman honorably with human standing as humanity [6]. Marriage in religious aspect nor society of life is sacred incident, but if see in from law aspect, marriage is not sacred incident only, but it is law incident which own due to certain laws [7]. The principal of marriage for to make inner bond forever and isnot temporary, which to end more. On the basis of inner bond, can be built peaceful household and regular, as well as get offspring in society [8].

Marriage according to national law is legal if it is carried out according to the provisions of Article 2 paragraph (1) of Law Number 1 of 1974 concerning Marriage which affirms that Marriage is legal if it is carried out according to the laws of each religion and its belief. Based on the provisions of Article 2 paragraph (1) it can be understood that a new marriage is considered valid if it is carried out according to the laws and religious procedures that the prospective bride and groom embrace. In fact, it can happen that a pair of prospective brides turns out to have different beliefs or religions, so that they are constrained to carry out marriages in Indonesia with the provisions of Article 2 paragraph (1) of Law Number 1 of 1974 concerning Marriage which does not provide space for interfaith marriages, considering Marriage must be carried out according to the laws of each religion and belief [9].

For couples who have financial ability, they will get married abroad, while for couples who do not have financial ability, they will choose one of the religious laws that will be used to carry out the marriage. Several interfaith couples who choose to marry abroad include Sarah Sechan with Neil G Farano who married in LA, United States in 2010, Kinaryosih and Breet Lee who married in Australia in 2012[10].

Research conducted by Sri Wahyuni shows in Gunung Kidul Regency, there is a practice of interfaith marriage in which one partner follows the other spouse's religious marriage procedure at the Wonosari Catholic Church (Saint Petrus Kanisius), where 
the only marriage based on the Catholic religion is performed, there is an average of $32 \%$ per year couples from a different religion. Meanwhile, in several KUAs, an average of $2.5 \%$ of couples come from different religions [11].

Interfaith marriages, which are widely practiced in the community, will in the long term have a social and psychological impact on children born to these couples, while in terms of legal aspects, they certainly have legal consequences for children born to different religious couples. This research, focus at the problem of consequences for children who born in interfaith marriage law and legal standing of children by their parents. Based on the description above, it is interesting to raise the issue regarding Interfaith Marriage and its Legal Consequences for Children Born According to Islamic Law.

\section{METHODS}

Methods This research uses a normative juridical method by reviewing various literatures relevant to the theme being studied. Data was collected through literature study to find secondary legal materials relevant to the prescriptive descriptive approach.

\section{RESULT AND DISCUSSION}

\section{Marriage Requirements Must be Follow According to Islamic Law}

A marriage must meet the requirements and pillars that have been determined by each religion and belief. Islamic law has regulated the terms and conditions of marriageas follows [12]:

a. The groom-to-be, the conditions
1) Moslem
2) boy
3) clears person
4) give consent
5) there are no marriage barriers

b. The prospective bride, the conditions:
1) Moslem
2) girl
3) clears person
4) asking for approval
5) there are no barriers to marriage.

c. Marriage guardian, the conditions are:
1) boy
2) mature
3) have guardianship 
4) there are no marriage barriers

d. Marriage witness, the conditions are:

1) Minimum two men

2) Present in the qabul

3) Can understand the meaning of the akad

4) Moslim

5) Adult

e. Ijab qabul, the conditions are:

1) There is a marriage statement from the guardian

2) There is a statement of acceptance from the prospective groom

3) Using the words marriage

4) Between consent and qabul is continuous

5) Between consent and qabul the meaning is clear

6) The person who is related to the ijab qabul is not in ihram

7) The Ijab Qabul Assembly must be attended by at least four people.

The conditions and pillars of marriage as described above must be fulfilled, otherwise the marriage will be invalid. Marriage is not valid if it is fasid (marriage that does not meet the conditions), or bathil (marriage that does not fulfill its pillars).

\section{Interfaith Marriage}

Interfaith marriages according to the Islamic view are marriages between Muslim men and non-Muslim women or vice versa. The practice of marriage in Indonesia is still actual, because according to Ahmad Rofiq, interfaith marriages are always related to creed issues and have a lot of negative impacts, both between husbands, wives, and children from interfaith marriages [13].

According to Mahjudin, Inter-religious marriages can be interpreted as marriages of two people of different religions, beliefs or understandings. "According to abd. Rozak, interfaith marriage is a marriage between a man and a woman who both have different religions or beliefs from each other[14].

Interfaith marriages can occur between Indonesian citizens or between Indonesian citizens and foreign nationals who both have different religions/beliefs.

Based on some of the opinions above, it can be concluded that interfaith marriages are marriages carried out by a man and a woman who have different religions/beliefs either by following one of the religious procedures adopted by one partner or by recording in other countries that provide opportunities for it.

\section{Consequences of Interfaith Marriage Law for Children Born According to Islamic Law}

Law according to Islam is seen as part of religious teachings, and legal norms are rooted in religion. Muslims believe that Islamic law is based on divine revelation. The law is therefore, called Sharia, which means the path that God has outlined for 
mankind [15]. Islamic Sharia maintains andmaintain moral values. For this purpose, there are many provisions in sharia to maintain and protect each moral value.

Marriage is something sacred for the majority of Indonesian people, so everyone who wants to get married will really prepare themselves according to the demands of their religion/belief.

The pillars and conditions of marriage determine a law, especially regarding the legality of a marriage. Marriage is a whole that is directly related to marriage with all its elements, not just the marriage contract itself, but the pillars of the marriage requirements are all things that must be realized in a marriage, both involving internal and external elements. The socio-cultural development of the community shows a shift in the meaning of a marriage which was originally seen as part of a form of worship, now it is only considered a physiological need. This condition affects the attitude of a person who will marry.

The terms and pillars of marriage are only considered as rituals without meaning, so it is not uncommon for couples to be married to ignore each other's religion/beliefs. This attitude is the starting point for the practice of interfaith marriage.

In the realm of Islamic law, a marriage must meet the requirements and pillars as regulated in Islamic jurisprudence. This is also confirmed in the provisions of Article 2 paragraph (1) of Law Number 1 of 1974 concerning Marriage. It is stated in the provisions of Article 2 paragraph (1) of Law Number 1 of 1974 concerning Marriage that marriage is legal, if it is carried out according to the law of each religion and belief. From these provisions, it can be understood that a marriage can only be carried out according to the laws of each religion or belief held by the prospective bride, so that the prospective bride must be of the same faith. If the prospective bride and groom have different beliefs, then marriage is not possible because the terms and pillars of marriage of each religion are different from one another.

The provisions of Article 2 paragraph (1) of Law Number 1 of 1974 concerning Marriage is one of the principles adopted by the Marriage Law, namely marriage is only valid if it is carried out according to the law of each religion and belief.

Rosnidar explained that a marriage will be considered valid if the marriage is carried out according to religious law or religious beliefs held by the prospective bride. Both prospective bride and groom must be of the same religion or faith, unless the law of their religion or belief dictates otherwise[16].

Article 40 letter c KThe compilation of Islamic Law expressly prohibits a Muslim man from marrying a woman who is not Muslim, as well as the provisions of Article 44 of the Compilation of Islamic Law which expressly states that a Muslim woman is prohibited from marrying a man who is not Muslim.

The existence of two articles that prohibit a Muslim man and a Muslim woman who forbids marriage to non-Muslims has closed the opportunity for interfaith marriages.

A Muslim man or a Muslim woman who marries a non-Muslim partner, then the marriage is considered invalid because it does not fulfill the conditions for a valid 
marriage according to Islamic law. In such a position, if they marry in a manner outside of Islamic law, it will have legal consequences for the child who is born. This is also reinforced by the opinion of Tihami and Sohari Sahrani that the marriage contract or marriage that cannot fulfill the pillars and conditions is a marriage it is invalid.

Presented by Ibnu Hazm that it is not permissible for a Muslim woman to marry a man who is not a Muslim, nor is it permissible for an infidel to have a Muslim slave and a Muslim female slave [11].

Allah SWT expressly says in Surah Al Baqarah verse 221 which reads:

"And do not marry idolatrous women until they believe. Verily, a believing slave woman is better than a polytheist woman, even if she attracts your heart. And do not marry the polytheists (to believing women) until they believe. Verily, a believing slave is better than a polytheist even if he attracts your heart. They invite to hell, while Allah invites to heaven and forgiveness with His permission. And Allah explains His verses (His commandments) to people so that they may take lessons."

Based on the provisions of the verse, it can be understood that according to Islamic law, Islam prohibits interfaith marriages so that if interfaith marriages occur, the marriage is not recognized or considered invalid according to Islamic law.

As previously explained that the marriage according to Islamic Law have to meet the requirement and pillar of marriage. Generally, requirement of Islamic marriage as follows:

a. There are the groom-to-be and, the prospective bride

Must be the groom-to-be and the prospective bride to show that in Islamic Law unknown same sex marriage between woman with woman or man with man. Islam is very hard on same sex marriage and Allah SWT cursed same sex marriage like historical story the destruction of the soddom and gomorah in era prophet Luth AS. The groom-to will marriage with the prospective bride, according to Islamic Law must be meet the requirements as follow:

1) He must be moslem

2) Clear person

3) He can give consent

4) there are no marriage barriers

The prospective bride will marriage with the prospective bride, according to Islamic Law must be meet the requirements as follow:"

1) She must be moslim

2) Clear person

3) She asking for approval

4) There are no marriage barriers

b. There is marriage guardian by the prospective bride 
A marriage guardian according to Islamic Law must be meet the requirements as follow:

1) He must be manS

2) He is mature

3) He have guardian right

4) there are no marriage barriers

c. There are two witness of marriage

A witness of marriage according to Islamic Law must be meet the requirements as follow:

1) Who must be man

2) He must be moslim

3) He must be mature

4) He must be present in ijab qabul

5) He must be understand about akad Islam

d. There are Ijab qabul

Ijab qobul is process to message marriage statement and acceptance of marriage. According Islamic Law process of ijab qobul must be meet the requirements as follow:

1) In ijab qobul there is a marriage statement from the guardian

2) In ijab qobul there is a statement of acceptance from the prospective groom

3) In ijab qobul using the words marriage

4) In ijab qobul between consent and qabul is continuous

5) In ijab qobul between consent and qabul the meaning is clear

6) In ijab qobul the person who is related to the ijab qabul is not in ihram

7) In ijab qobul Assembly must be attended by at least four people.

The marriage in Islam, if meet the requirements and pillar of marriage, marriage is legal, but if one requirements not meet and pillar marriage, marriage is illegal. One example requirements not meet is the groom-to or the prospective bride is not moslim, so this marriage according the Islamic Law impossible to realization because one requirement not meet is a moslim.

Islamic law regulary marriage barriers too or with other word is ban in marriage, that:

a. Who is banned to marriage with brotherhood, because between both have relation blood to close so that as be marriage barrier.

b. Who is man have said third talak to hiswife, banned to marriage again with her, except she have marriage with otherman and have intercourse so she divorced, can be marriage again.

c. A moslim banned marriage with non moslim. 
Based on three ban in marriage according to Islamic Law, religion different between them is one of ban marriage according to Islamic Law. Process of Marriage if one of them non be moslim, so that this marriage is illegal because there is one of requirement and pillar of marriage according to Islamic Law.

A fight that is considered invalid according to Islamic law, the logical consequence is that there is no acknowledgment of the marriage, so that everything that happens during the marriage cannot be resolved by Islamic marriage law, such as the problem of the position of children born from the marriage, joint property, inheritance and so on related to marriage.

In general, the marriage of parents of different religions has legal consequences for children born in relation to the relationship between the child and his parents, among others:

a. If his father is Muslim and his mother is not Muslim, then as long as he has not chosen which religion he will follow, he will be considered as following his father's religion. However, if it turns out that when he grows up he chooses to follow the religion of his mother who is not Muslim or a religion other than his parents (not Muslim) then this child will be cut off from his nasab relationship with his Muslim parents (father).

b. If his father is not Muslim and his mother is Muslim, then he is considered an illegitimate child, because he will be nationalized according to his father's lineage. But if it turns out that when he grows up he chooses to embrace Islam, then he only has a nasab relationship with his mother who is Muslim, and the nasab relationship (descendants) between him and his father is severed.

According to the provisions of Article 99 of the Compilation of Islamic Law, a child is legally considered valid if:

a. Children born in or as a result of a legal marriage

b. The result of legal husband and wife fertilization outside the womb and born by the wife.

Based on the provisions above, it can be understood that a child is considered legitimate as a descendant of both parents if it is born in or as a result of a legal marriage and the result of a legal husband and wife fertilization outside the womb and born by the wife. Children born from interfaith marriages are considered illegitimate, because interfaith marriages according to Islamic law are illegitimate marriages because they do not meet the requirements and pillars of marriage.

The legal consequences for children born from interfaith marriages according to Islamic law, marriages that do not meet the requirements and pillars of marriage according to Islamic law do not have a lineage from their father and are considered as children born out of wedlock. Children born out of wedlock according to the provisions of Article 100 of the Compilation of Islamic Law, only have a nasab relationship with their mother and their mother's family. 
From the description above, it can be understood that the legal consequence for children born to interfaith couples or interfaith marriages is that the child only has a kinship relationship with his mother and his mother's family.

\section{CONCLUSION}

Based on the description above, it can be concluded that a marriage must be follow requirements like Islamic Law, interfaith marriages according to Islamic law have legal consequences for children who are born, namely children are considered as children born out of wedlock. Children born out of wedlock only have a kinship relationship with their mother and their mother's family.

\section{REFERENCES}

[1] D. H. I. Muzammil, "Fiqh Munakahat (Hukum Pernikahan dalam Islam)," Journal of Chemical Information and Modeling, vol. 53, no. 9, 2019.

[2] Wagiyem, "( Komparasi Antara Fiqh Munakahat Dan Hukum Positif Di Indonesia )," Pendidikan Agama Islam, vol. 13, 1974.

[3] M. Furqan, "Pengembang Masyarakat Islam Di Indonesia," Jurnal Al-Ijtimaiyyah: Media Kajian Pengembangan Masyarakat Islam, vol. 5, no. 1, 2019.

[4] M. Isnaeni, Hukum Perkawinan Indonesia, no. Cetakan ke II. 2016.

[5] M. AM, "Pembaharuan Hukum dalam Kompilasi Hukum Islam di Indonesia," Jurnal Ilmiah Al-Syir'ah, vol. 7, no. 1, 2016, doi: 10.30984/as.v7i1.57.

[6] E. Gunawan, "EKSISTENSI KOMPILASI HUKUM ISLAM DI INDONESIA,” Jurnal Ilmiah Al-Syir'ah, vol. 8, no. 1, 2016, doi: 10.30984/as.v8i1.39.

[7] T. Taufiqurrahman, "Kompilasi Hukum Islam: Suatu Formalisasi Syariat Islam di Indonesia," AL-IHKAM: Jurnal Hukum \& Pranata Sosial, vol. 1, no. 2, 2019, doi: 10.19105/al-lhkam.v1i2.2559.

[8] N. Mubarok, "Sejarah Hukum Perkawinan Islam di Indonesia," Al-Hukama, vol. 02, no. $2,2012$.

[9] M. Mukhlis, "Pembaharuan Hukum Perkawinan Di Indonesia," ADLIYA: Jurnal Hukum dan Kemanusiaan, vol. 11, no. 1, 2019, doi: 10.15575/adliya.v11i1.4852.

[10] A. Amri, "Perkawinan Beda Agama Menurut Hukum Positif dan Hukum Islam," Media Syari'ah, vol. 22, no. 1, 2020, doi: 10.22373/jms.v22i1.6719.

[11] Z. Syafe'i, "Kontroversi Hukum Perkawinan Berbeda Agama," ALQALAM, vol. 24, no. 1, 2007, doi: 10.32678/alqalam.v24i1.1659.

[12] M. N. Yasin et al., "Hukum Perdata Islam di Indonesia," Journal de Jure, vol. 7, no. 1, 2016.

[13] A. Yumni, "Masail Fiqhiyah Dalam Konteks Sosial Budaya," NIZHAMIYAH, vol. 8, no. 1, 2018, doi: 10.30821/niz.v8i1.249.

[14] Abd. Rozak A., "Pengkajian Hukum Tentang Perkawinan Beda Agama (Perbandingan Beberapa Negara)," Badan Pembinaan Hukum Nasional (BPHN) Kementerian Hukum dan Hak Asasi Manusia, vol. 53, no. 9, 2011.

[15] M. L. Nurcahyono, "Pembaruan Metode Penemuan Hukum Islam: Pendekatan Terpadu Hukum Islam dan Sosial," Ulumuna, vol. 16, no. 1, 2012, doi: 10.20414/ujis.v16i1.188.

[16] T. Erwinsyahbana, "Aspek Hukum Perkawinan Antar Agama Dan Problematika Yuridisnya," Refleksi Hukum: Jurnal Ilmu Hukum, vol. 3, no. 1, 2019, doi: 10.24246/jrh.2018.v3.i1.p98-114. 